\title{
A adivinhação no Egito faraônico
}

\author{
CIRO FLAMARION S. CARDOSO \\ Departamento de História \\ Instituto de Ciências Humanas e Filosofia \\ Universidade Federal Fluminense
}

RESUMO: Toda a adivinhação no Egito tinha laços com o sagrado. Os dois tipos conhecidos, a oniromancia, com documentação relativamente escassa, e os oráculos, com fontes mais numerosas, iluminam tanto as esferas do poder faraônico e sacerdotal quanto o cotidiano popular. Através da apresentação de exemplos específicos de adivinhaçäo e das controvérsias nas suas explicações, conclui-se que no Egito antigo perdurava a noção de que, longe de serem entidades remotas e distantes, os deuses - ou pelo menos alguns deles - tomavam parte da vida cotidiana dos reis, dos poderosos e igualmente das pessoas humildes.

PALAVRAS-CHAVE: Egito faraônico, adivinhação, oniromancia, oráculos.

\section{Generalidades}

Entre os antigos egípcios, o esforço para adivinhar o futuro - mas igualmente pontos obscuros do passado e do presente - tomava duas formas principais: a interpretação dos sonhos e os oráculos divinos.

As funções da adivinhação eram análogas às do pensamento científico no mundo de hoje: tornar o universo inteligivel e, assim, permitir aos homens a ação sobre realidades que lhes pudessem dizer respeito. Não houve, porém, uma sistematização lógica dos procedimentos mânticos similar àquela que se constata ao ler o escrito do professor Jean Bottéro contido neste volume.

Os oráculos eram considerados manifestações diretas dos deuses - através de suas imagens, de animais sagrados em que se encarnavam parcialmente, ou às vezes pela boca de seus sacerdotes. Sendo os sonhos encarados como advertências divinas, podemos concluir, então, que toda adivinhação tinha estreitos laços com o sagrado:

Quando o homem crê que a divindade participa de seu destino e o dirige no detalhe, ele formula ao mesmo tempo o desejo de descobrir o que ela decidiu a seu respeito e o que lhe aconselha fazer. [Erman, 1952, p. 186] 
A documentação acerca da oniromancia é relativamente escassa. As fontes mais numerosas que chegaram até nós tratam do outro aspecto básico da adivinhação no Egito antigo, ou seja, dos oráculos divinos. Mas em ambos os casos, os textos iluminam tanto as altas esferas do poder faraônico e sacerdotal quanto o cotidiano de pessoas humildes. Sublinhando todas as circunstâncias e modalidades da adivinhação estava a convicção de que os deuses, melhor do que os mortais, poderiam apreciar a justiça de uma queixa, a oportunidade e o bom fundamento de um requerimento ou de uma tramitação, aconselhar a ação mais adequada a empreender, melhor do que os policiais e juizes, saberiam encontrar um ladrão e provar a sua culpa. As questões submetidas aos oráculos eram as mais diversas que se possa imaginar.

Naturalmente, os problemas apresentados aos deuses não eram os mesmos ao tratar-se do vulgo ou, pelo contrário, de um rei ou sumo-sacerdote. No primeiro caso, as perguntas tinham a ver com roubos, curas, casamentos, viagens, rações, e muitas vezes buscavam estabelecer a inocência ou a culpa em situações corriqueiras, típicas do dia-a-dia de uma dada comunidade urbana ou aldeã. Quando um rei ou um sumo-sacerdote buscava auscultar a opinião da divindade, as perguntas se referiam a guerras e calamidades públicas, a grandes obras, à nomeação de funcionários, ao eventual castigo de funcionários culpados. Durante a XVIII dinastia, o oráculo de Amon interveio em mais de uma ocasião em questões atinentes à própria legitimidade do poder do faraó reinante ou de um pretendente ao trono'.

\section{A oniromancia}

Como acontece com tudo que se refere à adivinhação no antigo Egito, as fontes disponíveis a respeito da oniromancia só se iniciam com o Reino Novo, isto é, em meados do segundo milênio a.C., embora a origem primeira de algumas delas seja atribuida a épocas anteriores. Na sua maioria, os casos que conhecemos se referem a reis.

$\mathrm{O}$ exemplo mais célebre - se bem que muito romanceado e bem improvável na forma em que o conhecemos - é o do faraó Djehutimés (Thotmés) IV, da XVIII dinastia (1401-1391 a.C.). Numa estela de granito datada do primeiro ano de seu reinado, achada entre as patas da grande esfinge de Gizeh, conta o rei que, sendo ainda um príncipe, caçava no deserto, na região de Mênfis, tendo adormecido ao meio-dia à sombra da estátua gigantesca. $O$ deus solar que a esfinge representa apareceu-lhe então num sonho, prometendo-lhe a realeza e solicitando que, uma vez rei, livrasse sua imagem da areia do deserto que a recobria em grande parte. Eis aqui, numa passagem do texto, as palavras do deus:

Contempla-me, olha-me, ó meu filho Djehutimés! Eu sou teu pai, Hórus no horizonte-Khepri-Re-Atum. Eu te darei a realeza sobre a terra, à frente dos vivos. Tu usarás a Coroa Branca e a Coroa Vermelha, no trono de Geb, príncipe [dos deuses]. Tua 
será a terra, em seu comprimento e em sua largura, a totalidade daquilo que ilumina - Olho do Senhor de Tudo. Tu serás o guardião da subsistência que provém do solo, receberás abundantemente tributo de todos os países estrangeiros, e a duração de tua vida será rica em anos. [Cumming, 1984, p. 247-9]

Se considerarmos que este rei não chegava a ter vinte anos quando sucedeu ao pai, o episódio da caçada "de leões e outros animais" no deserto vários anos antes, acompanhado - diz-nos a fonte - de um único serviçal, não é crivel. A impressão que se tira de tudo isso é que o príncipe, não sendo provavelmente o filho mais velho do faraó precedente, tentava demonstrar ter ocorrido uma aprovação divina à sua tomada do poder, muito antes de que ela ocorresse. Em todo caso, a forma escolhida para o fazer mostra que os egípcios acreditavam poder, em sonhos, receber a visita de uma divindade. A egiptóloga Claire Lalouette vê também, neste episódio em que não é Amon de Tebas o deus oficial da dinastia reinante, e sim o deus solar de Heliópolis, a divindade que assegura a legitimidade do soberano, um primeiro sinal da vontade faraônica de desprender-se do clero da capital e, ao mesmo tempo, de aproximar-se do Baixo Egito - prenunciando, respectivamente, a futura heresia de Akhenaton, neto de Djehutimés IV, e a política favorável ao Norte da dinastia seguinte (Lalouette, 1986, p. 414-5).

Um outro exemplo de intervenção divina em sonhos — desta vez trata-se de Ptah de Mênfis - é narrada por Heródoto (II, 141), e se refere talvez (as circunstâncias e a cronologia são, neste caso, das mais inseguras) à primeira metade do século VII a.C., quando das invasões assírias no Egito. Diante do avanço das tropas do rei assírio Sennaquerib, os guerreiros egípcios se negaram a combater. Um sacerdote de Ptah chamado "Sethon", que segundo Heródoto se tomara rei, foi implorar no templo à estátua de seu deus:

Em meio a suas lamentações, foi tomado pelo sono e acreditou ver em sonho o deus, de pé perto dele, encorajá-lo e prometer-lhe que mal algum lhe adviria se marchasse contra o exército semita: ele the enviaria defensores. [Hérodote-Thucydide, 1964, p. 200]

Confiando na promessa divina, Sethon, armando um exército de comerciantes e artesãos, defendeu Pelusa, na extremidade leste do Delta, derrotando o inimigo. Esta narrativa de Heródoto, eivada de incorreções históricas e contendo mesmo, em sua continuação, uma intervenção mágica de "ratos do campo" contra os assírios, é das mais suspeitas. Não somente o rei-sacerdote Sethon carece de confirmação nas fontes egípcias (na época de Sennaquerib reinaram no Egito sucessivamente Shabaka, Shebiktu e Taharka, reis da XXV dinastia, proveniente da Núbia), como também não data dessa época, e sim de 674 a.C., sob o rei assírio Esarhaddon, a primeira tentativa (fracassada) de invasão do próprio Egito. Anteriormente, um embate entre egípcios e assírios só se havia dado na Palestina, onde Shabaka apoiara com uma tropa, em 701 a.C., o reino de Judá. 
Um documento proveniente de um meio social completamente diverso - homens do campo com certos bens, segundo alguns autores; pessoas de uma pequena cidade de província, segundo uma opinião diferente - é o que contém o papiro Chester Beatty III, publicado por Gardiner e conhecido como "a chave dos sonhos". Este texto é atribuído ao começo do segundo milênio a.C., se bem que a cópia que possuímos seja mais tardia, do século XIII ou XII a.C.. O seu conteúdo é curioso, ligando-se a gente muito preocupada com assuntos como o aumento ou a diminuição de sua riqueza, a aquisição ou a perda de posições na administração local, a possibilidade de ver-se privada de mão-de-obra etc. Os sonhos podem ser, então, favoráveis ou nefastos, e sua interpretação permite adivinhar o futuro quanto a aspectos precisos. Eis aqui dois exemplos, relativos respectivamente ao acesso a funções administrativas locais e à condição de líder, também local: "Se quem dorme vir-se navegando num barco, é bom: é que ele vai ter autoridade entre seus concidadãos". Se o sonhador vir-se, em sonho, "conduzindo de volta o gado, algo de bom lhe acontecerá: seu deus vai reunir as pessoas para ele" (Gardiner, 1937, p. 9-23).

Não poderíamos deixar o tema da oniromancia sem recordar o conhecido episódio biblico em que José, filho de Jacó, interpreta na prisão sonhos do copeiro e do padeiro do rei do Egito, e depois, no palácio, os sonhos do próprio faraó (Gênesis, 40- 41) ${ }^{2}$.

$\mathrm{O}$ episódio em si não tem comprovação paralela em documentos egípcios e é impossível de datar (XIX dinastia?); no entanto, as interpretações mesmas que, no texto, são oferecidas por José, são de tipo semelhante às contidas na "chave dos sonhos" egípcia a que já nos referimos. Por outro lado, um documento egípcio muito posterior, de época ptolomaica, a inscrição da ilha de Sahel, em Elefantine (extremo sul do Egito), atribui a Djéser, da III dinastia (2630-2611 a.C.), um episódio de oniromancia que, como nos sonhos do faraó da história de José, refere-se a sete anos de penúria e fome, em que o Nilo não inundou os campos. $O$ deus local Khnum, em um sonho do faraó, profetizou-lhe o fim da calamidade, recebendo em troca do soberano copiosas doações de riquezas, terras, gado, mão-de-obra e produtos da Núbia. Em sua forma disponível, a inscrição é indubitavelmente helenística, e portanto mais de dois milênios posterior à época de Djéser. Muitos especialistas a consideram uma falsificação pura e simples dos sacerdotes de Khnum, com o fito de justificar e defender as suas propriedades em Elefantine; uma minoria a vê como texto baseado num decreto autêntico do Reino Antigo. Note-se, ainda, que a tradição relativa a sete anos de fome era muito difundida nas literaturas do antigo Oriente Próximo (Lichtheim, 1980, p. 94-100).

\section{Os oráculos divinos}

À relativa escassez de materiais acerca da oniromancia opõe-se uma riqueza bem maior de fontes sobre os oráculos divinos, aspecto por isto mesmo muito mais estudado e conhecido da adivinhação no antigo Egito ${ }^{3}$. 
Heródoto, numa parte de sua obra em que compara costumes e características da Grécia e do Egito, observa que, entre os egípcios, eram os deuses que, diretamente, faziam conhecer sua vontade ou sua opinião, sem a ação de seres humanos considerados inspirados ou portadores de dons especiais; diz ainda que os oráculos egípcios não eram todos consultados do mesmo modo, havendo diferentes procedimentos oraculares $(\text { II, } 83)^{4}$. Estas observações, absolutamente corretas, aplicam-se a todo o período para o qual temos documentação relativa aos oráculos, de meados do segundo milênio a.C. até o período greco-romano da história do Egito.

A forma mais freqüente da consulta oracular consistia em interrogar a estátua divina quando passeava em sua barca sagrada, no próprio templo ou na rua. Levada aos ombros pelos sacerdotes, a barca oscilava num sentido ou no outro, avançando ou recuando, o que queria dizer respectivamente "sim" ou "não". Ao se tratar de casos mais complexos, a estátua podia escolher entre textos alternativos escritos em placas de madeira, fragmentos de pedra lisa ou de papiro, designando a resposta correta. Algumas fontes mencionam também vozes proféticas que se faziam ouvir, à noite, nos santuários. Por fim, o deus podia se exprimir através de um ser vivo: um sacerdote ou um animal sagrado (como os touros Ápis e Mnévis). Os animais sagrados que podiam servir ao processo oracular eram chamados de "relatores" dos deuses. Isto quer dizer que o seu papel era de intermediários: eles faziam chegar informações ao deus, fornecendo-lhe elementos para formar uma opinião. De modo análogo, os sacerdotes encarregados de redigir as perguntas feitas ao oráculo e interpretar os signos oraculares eram chamados "servidores do deus que fazem relatos". Mesmo quando a divindade falava pela boca ou através dos gestos de um ser vivo, não se considerava necessário qualquer dom ou talento especial do ser em questão, atribuindo-se a manifestação do oráculo em forma direta e completa ao deus (Posener et al., 1970, p. 200-1; Allam, 1969; Morenz, 1977, p. 142-3).

O faraó, ao mesmo tempo deus e homem, era o intermediário natural entre os egípcios e os seus deuses. Os oráculos divinos - como os sonhos e os milagres ou prodígios - constituiam uma das formas pelas quais o monarca tratava de averiguar os desígnios divinos para orientar a sua ação segundo as instruções dos deuses. No tocante ao final da XVIII ${ }^{\mathrm{a}}$ dinastia, Wilson fala mesmo a respeito de um "controle oracular" do faraó pelo deus Amon - ou seja, pelos sacerdotes deste deus - o que é, sem dúvida, excessivo (Wilson, 1951, p. 216).

Seja como for, a rainha Hatshepsut (1473-1458 a.C.), por exemplo, confirmou por meio de um oráculo de Amon (por ela proclamado como seu pai carnal) a sua decisão de enviar uma expedição marítima ao "país de Punt", possivelmente a costa da Somália, em busca de madeiras preciosas, incenso, mirra e outros podutos:

Uma ordem foi ouvida, proveniente do grande trono, um oráculo do próprio deus, para que fossem procurados caminhos em direção a Punt e abertas estradas em direção aos terraços do incenso; o exército deverá ser conduzido por mar e por terra, com a finalidade de trazer as maravilhas do país divino para este deus que deu 
forma à sua beleza [i.e., à beleza da rainha]. Agiu-se, pois, conforme tudo o que fora ordenado pela Majestade deste deus augusto; conforme, também, o desejo de Sua Majestade [a minha] a este respeito. [Lalouette, 1986, p. 247]

Antes de mais nada, porém, era preciso estabelecer, além de qualquer dúvida, a legitimidade do próprio poder do rei-deus. Isto podia ser feito, como já vimos, através do relato de um sonho profético, por meio de um mito teogâmico (como o que atribuiu a Amon a paternidade carnal de Hatshepsut), ou recorrendo ao oráculo divino, a um "decreto do deus". O exemplo mais conhecido deste último procedimento de legitimação refere-se a Djehutimés III (reino pessoal, após a usurpação de Hatshepsut, entre 1458 e 1425 a.C.). Uma inscrição no templo de Amon em Karnak conta que o jovem príncipe Djehutimés servia no templo como sacerdote de categoria inferior, sob o reinado de seu pai. Um dia em que o monarca reinante viera sacrificar a Amon, a estátua do deus pôs-se a circular entre as colunas do santuário, buscando o príncipe. Ao achá-lo, o jovem se prosternou diante do deus: Amon o levantou e o designou como futuro faraó. A intenção do texto era mostrar a eleição do rei (que nascera de uma esposa secundária de seu pai) para o cargo pelo deus dinástico, com o consentimento de seu pai e antecessor. Mas deve ser recordado que a inscrição de Karnak foi redigida quarenta e dois anos depois da data em que se teria produzido a intervenção do oráculo de Amon! (Lalouette, 1986, p. 202-4; Gardiner, 1979, p. 180-1).

Também o rei Horemheb, que não pertencia à dinastia reinante e governou de 1319 a 1307 a.C., julgou necessário legitimar a sua pretensão ao trono relatando como, ainda em vida de seu antecessor, o deus Hórus da sua cidade natal de Hutnesut o teria conduzido pessoalmente a Tebas, diante de Amon. Este, por ocasião da festa de Opet, ao ser transportado do templo de Karnak ao de Luxor em sua barca, o designou mediante um oráculo como sucessor do faraó Ai (Drioton e Vandier, 1952, p. 350).

Temos outros exemplos posteriores de oráculos relativos à designação do rei por uma divindade, bem como à justificação oracular de decisões reais importantes. Heródoto (II, 147, 152) narra que a reunificação do Egito por Psamético I, da XXVI ${ }^{a}$ dinastia, que reinou de 664 a 610 a.C., fora prevista por um oráculo do deus Ptah de Mênfis. O mesmo rei apelou para um oráculo da deusa Uadjet de Buto no sentido de justificar o seu emprego de mercenários jônios e cários na guerra de reunificação contra os dinastas egípcios rivais ${ }^{5}$.

Em todos estes casos de legitimação do poder ou de decisões do monarca reinante temos, ao que parece, oráculos fictícios, inventados post eventum - procedimento de que há também usos de outros tipos na história do Egito ${ }^{6}$.

Mencionemos ainda o oráculo famoso em que "Zeus Ammon" - duvida-se de que se trate do mesmo deus de Tebas -, no seu santuário de Siwah, reconheceu Alexandre, o Grande da Macedônia como seu filho, rei do Egito e soberano universal, em 332 a.C. (Baines e Málek, 1980, p. 52).

Nos grandes templos do Egito faraônico, a partir do Reino Novo, a nomeação de sacerdotes e de funcionários administrativos se fazia, igualmente, mediante oráculos. 
Dispomos da descrição do processo de indicação do sumo-sacerdote de Amon por Ramsés II, da XIX dinastia, no início do seu reinado pessoal, por volta de 1279 a.C.: os nomes dos candidatos foram lidos sucessivamente diante da imagem oracular do deus, até que esta, depois de recusar vários nomes, aprovou o do candidato preferido pelo rei - um sacerdote estranho ao clero de Amon, Nebuenenef. Uma cena acompanhada de inscrição, numa parede de Karnak, representa algo freqüente sob a XXa dinastia: um escriba dos celeiros de Amon deve ser nomeado: o deus, em sua barca, "se inclina" fortemente em direção ao candidato, Nesamon, confirmando sua escolha para o cargo; nesta ocasião, o próprio sumo-sacerdote interroga a divindade. Obviamente, os funcionários da administração templária suspeitos de desviar recursos, ou de outras infrações, deviam também submeter-se ao julgamento do oráculo divino (Kitchen, 1982, p. 44-6; Gardiner, 1979, p. 305; Maspéro, 1912, p. 62-9).

Textos achados sobre estátuas de funcionários, provenientes do templo de Mut em Karnak e talvez do de Ísis em Coptos (Museu do Cairo, peças 901 e 627), mostram que, além do rei e dos sacerdotes, outros fiéis de alta hierarquia se dirigiam aos santuários para consulta dos oráculos. No século X a.C., o chefe libio Sheshonk, que depois seria faraó, consultou em Tebas o oráculo de Amon acerca do culto funerário de seu pai Nemrod e da possibilidade de passar a exercer as funções que haviam sido deste último, recebendo do deus respostas favoráveis. Também sob a XXII dinastia, conhecemos uma consulta a Ptah de Mênfis para saber se aprovava uma doação que lhe queria fazer um particular - coisa em que consentiu o oráculo do deus (Morenz, 1977, p. 142; Drioton e Vandier, 1952, p. 518, 523; Sainte Fare Garnot, 1952, p. 186).

A partir do final da $\mathrm{XX}^{\mathrm{a}}$ dinastia e sob a dinastia seguinte, nos séculos $\mathrm{XI}$ e $\mathrm{X}$ a.C., quando a região de Tebas estava, com todo o sul do Egito, sob a administração do sumo-sacerdote de Amon, praticamente tudo que tinha a ver com a vida tebana era submetido à aprovação oracular do deus: um dote principesco; a condenação e depois o perdão de pessoas banidas num oásis; o destino glorioso dos mortos mas também a proteção dos vivos contra seus eventuais maleficios, dando lugar a copiosos "decretos" obtidos por via oracular (Posener et al., 1970, p.252; Drioton e Vandier, 1952, p. 51920; Vandier, 1949, p. 154-5). Isto pode indicar um enfraquecimento da autoridade governamental num Egito politicamente dividido, levando a lançar mão dos oráculos até mesmo para dar força a decisões políticas e administrativas menores (O'Connor, 1983, p.199).

O peso dos oráculos era decisivo nessa época, em matéria de administração, em diversas partes do Egito. No quinto ano de Sheshonk I (aproximadamente 940 a.C.), direitos de certos particulares ao uso de poços no oásis de Dakhleh foram estabelecidos por quatro oráculos de Seth, confirmando o testemunho do sacerdote local da mesma divindade (Gardiner, 1933).

Embora sejam bem mais numerosos os documentos que se referem aos oráculos de Amon em Karnak, sabemos da existência de diversos outros santuários cujos deuses ou representantes seus (como os animais sagrados) respondiam a consultas oraculares: a deusa Ísis em Coptos, o touro Bukhis em Medamud, o semideus ou gênio Bés em 
Abidos, o touro Ápis e o deus Ptah em Mênfis, a deusa Uadjet em Buto. No século V a.C., quando Heródoto visitou o Egito, era o oráculo de Buto que gozava, segundo o grego (II, 83 e 155), de maior prestígio. Nessa época tardia, influências dos sistemas oraculares gregos eram perceptíveis, as quais aumentaram ainda no período greco-romano (Posener et al., 1970, p. 201; Hérodote-Thucydide, 1964, p. 173, 297; Hani, 1976, p. 431).

Até aqui nos referimos a exemplos de oráculos ligados aos reis e aos templos oficiais da religião estatal. É possível, porém, que o hábito da consulta oracular tenha sido, primeiro, uma atitude religiosa popular - talvez muito antiga, embora faltem provas - que, só no Reino Novo, acabou por invadir, aos poucos, a esfera oficial. Começamos a conhecer melhor o tema em seu aspecto popular, no tocante às $\mathrm{XIX}^{\mathrm{a}} \mathrm{e} \mathrm{XX}^{\mathrm{a}}$ dinastias, graças à copiosa documentação preservada a respeito (sobretudo em placas de pedra contendo textos) no povoado dos construtores das tumbas reais tebanas, em Deir el-Medina. Alguns estudos começam também a mostrar a persistência posterior do recurso popular aos oráculos (Menu, 1984, p. 41; Seidl, 1966; Bierbrier, 1982, p. 98-9).

Em Deir el-Medina, era o deus Amon, em três formas locais, que servia às consultas, mas em concorrência com o faraó Amenhotep I divinizado (venerado pelos trabalhadores como fundador e patrono do seu povoado). Na extremidade norte da aglomeração habitada pelos artesãos funerários havia vários santuários, sendo o de Amenhotep I o principal. A sua imagem, carregada em procissão por ocasião das festas por seis dos artesãos purificados ritualmente como sacerdotes, podia ser interrogada pelas ruas: o sistema funcionava como uma miniatura do grande oráculo de Amon em Karnak. O mais interessante, entretanto, é que, ao lado do conselho de anciãos (kenebet) local, que se reunia ordinariamente como tribunal, havia outro de base oracular, no qual a estátua do rei divinizado decidia em última instância $\mathrm{O}$ oráculo de Amenhotep I continuou a funcionar em Deir el-Medina por algum tempo depois do abandono do povoado, tal o seu prestígio (Allam, 1969; Vandier, 1949, p. 231-2; Romer, 1984, p. 102, 200).

Dispomos de um número razoável de casos submetidos por populares em Deir el-Medina e posteriormente em outros lugares aos oráculos locais, da XIX ${ }^{\mathrm{a}}$ dinastia até o período greco-romano?

No início da $\mathrm{XX}^{\mathrm{a}}$ dinastia, no século XII a.C., ocorreu o roubo de cinco vestes que estavam sob a custódia de Amonemuia, funcionário dos depósitos da necrópole tebana. Este pediu a uma das formas locais de Amon que the indicasse oracularmente o culpado. Os nomes de todos os habitantes do povoado de Deir el-Medina foram lidos diante da estátua, até que esta designasse o ladrão. Este negou a sua culpa e apelou para o oráculo de outra forma local de Amon, que confirmou a acusação, e por fim para o de uma terceira forma local do deus; sempre inculpado, foi finalmente açoitado. Este caso é interessante por mostrar que, em certas ocasiões, admitia-se o recurso do resultado de um oráculo popular mediante a transferência da consulta a um outro oráculo (Daumas, 1972, p. 204-5).

Por volta de 1166 a.C., o oráculo de Amenhotep I interveio numa questão envolvendo a posse de uma tumba. Os artesãos de Deir el-Medina, que escavavam e decoravam os sepulcros reais, construiam também tumbas para si próprios e suas famílias, 
numa elevação rochosa próxima ao seu povoado. Com o tempo, o excesso de perfurações na pedreira trouxe o problema das disputas de posse, já que enterros mais recentes invadiam a área de sepulturas anteriores. No caso de que falamos, o artesão Amenemope conseguiu, no ano 21 do faraó Ramsés III, um decreto oracular do rei divinizado confirmando os seus direitos.

No ano 21, segundo mês da colheita, dia 1, eu me pus diante de Amenhotep, dizendo-lhe: "Dá-me uma tumba entre meus antepassados". Ele me deu a tumba de Hay por escrito. [Bierbrier, 1982, p.99]

Outras consultas populares preservadas em textos diziam respeito a assuntos variados do dia-a-dia: o roubo de uma esteira, a disputa de uma casa, a efetivação do pagamento de parcelas de terra vendidas etc. Foi usual, ainda, receber das imagens oraculares "decretos" de proteção para as crianças, garantindo-lhes que, por ordem do deus, não ficariam doentes nem se acidentariam. Elas usavam ao pescoço estojos cilíndricos contendo, num papiro, a cópia do oráculo protetor (James, 1979, p.109; Théodoridès, 1971, p. 317-8, nota 2; Romer, 1984, p. 102, 108-9, 111).

\section{Controvérsias historiográficas acerca dos oráculos egípcios e de seus usos políticos e judiciários}

Tanto no século passado como neste, o racionalismo à outrance viu, no mecanismo dos oráculos egípcios (como, aliás, no funcionamento de qualquer oráculo), somente uma fraude. Como certos textos se referem a uma inclinação de cabeça da imagem divina (significando, mais provavelmente, uma inclinação ou avanço da barca sagrada que continha a estátua), não faltou quem falasse de ídolos ocos movidos por cordéis... Em nosso século, Drioton e Vandier exemplificam esta corrente interpretativa, atribuindo os oráculos à pura e simples manipulação sacerdotal: chegam mesmo a falar na "comédia dos oráculos" (Drioton e Vandier, 1952, p.338, 454, 470) ${ }^{8}$.

Por mais que suspeitemos da existência de muitos casos de manipulação — sobretudo ao se tratar de oráculos divulgados décadas depois de supostamente terem ocorrido, para dar apoio divino à legitimidade do monarca reinante - , na maioria dos casos esta explicação é inaceitável. Parece óbvio que um sistema oracular não se sustentaria à base da pura fraude durante quase dois milênios - como ocorreu no Egito antigo, se considerarmos unicamente a fase bem documentada dos oráculos naquele país. Assim, são hoje mais comuns as tentativas de interpretação do fenômeno que invocam a sugestão e a auto-sugestão e aceitam, pelos menos na maioria das vezes, a sinceridade das pessoas envolvidas de uma ou outra forma no processo oracular ${ }^{9}$.

Outro tema de controvérsia é a suposta ligação entre decadência política e aumento dos aspectos religiosos no governo e na administração, incluindo a multiplicação das 
consultas oraculares como forma de fortalecer as decisões através do respaldo divino. $\dot{E}$ assim que Drioton e Vandier afirmam que, enquanto no apogeu imperial do Reino Novo se usava o oráculo um pouco como jogamos cara ou coroa, sem transformá-lo num meio de governar, com o enfraquecimento do poder monárquico ele se tomou exatamente isto, sobretudo na época em que os sumo-sacerdotes de Amon governaram Tebas e o sul do Egito, sob a XXI ${ }^{a}$ dinastia. Em forma mais nuançada, D. O'Connor ressalta que, no auge do Reino Novo, o regime empregava os oráculos para ratificar, $a$ posteriori, decisões políticas de alto nivel; mais tarde, porém, com a diminuição da autoridade faraônica, os decretos oraculares começaram a ser usados pelo governo para apoiar decisões administrativas e judiciárias menores, corriqueiras, que no passado não precisariam de tal apoio (Drioton e Vandier, 1952, p. 519-20; Vandier, 1949, p. 154-5; O'Connor, 1983, p. 199; Daumas, 1972, p. 204-5).

Quanto a este assunto, parece-nos que a afirmação específica está correta: o fato de ter ocorrido uma maior necessidade da ratificação oracular como resultado da progressiva perda de poder e prestígio da monarquia ao avançar a $\mathrm{XX}^{\mathrm{a}}$ dinastia. Mas não parece aceitável a implicação subjacente, nem sempre formulada com clareza, aliás, de que um aspecto "positivo" e "racional" deva ser atribuido ao poder laico, em oposição a um caráter "retrógrado" e "irracional" das decisões religiosamente apoiadas: implicação esta decididamente anacrônica, sendo impossivel, outrossim, uma teoria aceitável do regime estabelecido à volta de um governante divino que o apresente como um regime laico! Mesmo porque a intensificação da superstição, da religiosidade presente na prática política, em geral do peso político da religião, que se nota em muitos eventos e circunstâncias e não somente na emergência histórica dos oráculos (que, se existiram antes, não estão documentados), é fenômeno já claramente perceptível em pleno apogeu do poder faraônico, sob a XVIII ${ }^{\mathrm{a}}$ dinastia e sob os mais fortes dos Ramsés.

Discussões similares envolvem a existência da dupla jurisdição em Deir el-Medina: um tribunal oracular se superpunha, como vimos, ao conselho dos anciãos, no povoado dos artesãos construtores das tumbas dos faraós situadas no Vale dos Reis (oeste de Tebas). Certos autores insistem no aspecto sagrado e na arbitrariedade que implica uma decisão confiada a um deus - vendo no recurso aos oráculos uma espécie de falência do sistema judiciário "normal". Mas S. Allam e A. Théodoridès, em diversos escritos bem apoiados na documentação, vêm mostrando que o tribunal oracular presidido por Amenhotep I divinizado em Deir el-Medina - e que provavelmente ilustra estruturas similares existentes nas instâncias locais e populares do poder em cidades e aldeias egípcias (mas que alhures, fora da situação excepcional que representava um povoado de artesãos letrados, não geraram documentação escrita) - agia à base do Direito vigente e do exame de provas e testemunhos, exatamente como o conselho de anciãos. A razão do recurso à estátua oracular parece ter sido cercar as decisões de maior solenidade e autoridade. Coisa importante, salienta D. O'Connor, como mecanismo social para diminuição das tensões e conflitos locais. Os membros dos conselhos eram pessoas da própria região, muitas vezes parentes ou amigos das partes que se opunham nos processos, e sentiriam com freqüência a necessidade de submeter as suas 
decisões - que quase sempre expressavam o sentimento ou julgamento geral ou majoritário da comunidade - à ratificação de um árbitro divino, portanto neutro e indiscutível (Menu, 1984, p. 99; Morenz, 1977, p. 33; Allam, 1969; Théodoridès, 1963-1964; Théodoridès, 1969, p. 171-2; Théodoridès, 1971, p. 317-8; O’Connor, 1983, p. 199, 218).

\section{Conclusão}

Independentemente das controvérsias que acabamos de resumir, o apelo aos deuses através de diferentes formas de adivinhação — oniromancia, oráculos - ao surgir em plena luz histórica em meados do segundo milênio a.C., parece característico de uma qualidade nova desenvolvida no Reino Novo pela religião egípcia, a qual se pode notar tanto nos setores oficiais da realeza e dos templos quanto nas instâncias populares, exemplificados pelos artesãos-sacerdotes de Deir el-Medina. Referimo-nos à noção de que, longe de serem entidades remotas e distantes, os deuses - ou pelo menos alguns deles - tomavam parte na vida cotidiana dos reis, dos poderosos e das pessoas comuns igualmente. Eles eram refúgio dos inocentes - proclamando oracularmente a sua justificação diante de acusadores e detratores - e designavam os culpados para que fossem castigados: garantiam, portanto, que a justiça prevalecesse no dia-a-dia da comunidade, fosse ela a de um templo ou de uma aldeia.

Com outros aspectos de piedade também documentados, o uso crescente dos oráculos revela uma relação pessoal, intima, direta dos fiéis com a divindade. No Reino Novo, Amon aparecia tanto como grande deus dinástico, oficial, quanto como o defensor, o refúgio, a providência dos homens pobres e modestos, a cujos apelos não deixava de responder (Morenz, 1977, p. 144; David, 1982, p. 145).

\section{Notas}

1- Cf. Posener et al., 1970, p. 6, 200-1.

2- Cf. A Biblia de Jerusalém, 1981, p. 68-70.

3- Veja, por exemplo, Blackman, 1925 e 1926; Cerni, 1930, 1935, 1942 e 1972; Seidl, 1966.

4- Cf. Hérodote-Thucydide, 1964, p. 173.

5- Cf. Hérodote-Thucydide, 1964, p. 203, 206; Morenz, 1977, p. 310, n. 3; O'Connor, 1983, p. 250.

6- Veja, para o exemplo tardio da Crônica Demótica, Drioton e Vandier, 1952, p. 616.

7- Sobre a persissência dos oráculos populares na Época Tardia, veja Seidl, 1966.

8- Ver também Petrie, 1972, p. 55.

9- Por exemplo: Romer, 1984, p. 102; Sauneron, 1980, p. 95-6; O'Connor, 1983, p. 199. 


\section{Referências Bibliográficas}

ALLAM, S. Zur Gottesgerichtsbarkeit in der altägyptischen Arbeitersiedlung von Deir el Medineh. Mitteilungen des deutschen archäologisches Institutes. Abteilung Kairo, Moguncia, v. 24, p. 10-5, 1969.

BAINES, John e MÁLEK, Jaromír. Atlas of ancient Egypt. Oxford: Elsevier, 1980.

A BÍBLIA DE JERUSALÉM. São Paulo: Edições Paulinas, 1981.

BIERBRIER, Morris. The tomb-builders of the Pharaohs. Londres: British Museum Publications, 1982.

BLACKMAN, A. H. Oracles in ancient Egypt. Partes I e II. Journal of Egyptian Archaeology, London, v.11 e 12, p.249-55 e 176-85, 1925 e 1926.

CERNI, Jaroslav. Une expression désignant la réponse négative d'un oracle. Bulletin de l'Institut Français d'Archéologie Orientale [doravante BIFAO], Cairo, p. 491-6, 1930.

CERNI, Jaroslav. Questions adressées aux oracles. BIFAO, v.35, p. 41-58, 1935.

CERNI, Jaroslav. Deuxième série de questions adressées aux oracles. BIFAO, v. 41, p. 13-24, 1942.

CERNI, Jaroslav. Troisième série de questions adressées aux oracles. BIFAO, v. 72, p. 51-69 e XV-XXV, 1972.

CUMMING, Barbara. Egyptian historical records of the later Eighteenth Dynasty. Warmister: Aris \& Phillips, 1984, v.III.

DAUMAS, François. La civilización del Egipto faraónico. Trad. de H. Pardellans. Barcelona: Juventud, 1972.

DAVID, A. Rosalie. The ancient Egyptians: religious beliefs and practices. London: Routledge \& Kegan Paul, 1982.

DRIOTON, Étienne e VANDIER, Jacques. L'Égypte. 3 ed. Paris: Presses Universitaires de France, 1952. Coleção "Clio".

ERMAN, Adolphe. La religion des Égyptiens. Trad. de Henri Wild. Paris: Payot, 1952.

GARDINER, Alan H. The Dakhleh stela. Journal of Egyptian archaeology, London, v.19, p.1930, 1933.

GARDINER, Alan H. Hieratic papyri in the British Museum. $3^{\mathrm{a}}$ série. London: British Museum, 1937.

GARDINER, Alan H. Egypt of the Pharaohs. London: Oxford University Press, 1979.

HANI, Jean. La religion égyptienne dans la pensée de Plutarque. Paris: Les Belles Lettres, 1976.

HÉRODOTE-THUCYDIDE. Oeuvres complètes. Trad. de A. Barguet e D. Roussel. Paris: Gallimard, 1964. Coleção "Bibliothèque de la Pléiade".

JAMES, T. G. H. An introduction to ancient Egypt. London: British Museum Publications, 1979.

KJTCHEN, K. A. Pharaoh triumphant: the life and times of Ramessess II. Wamister: Aris \& Phillips, 1982.

LALOUETTE, Claire. Thèbes ou la naissance d'un empire. Paris: Fayard, 1986.

LICHTHEIM, Miriam. Ancient Egyptian literature. III. The Late Period. Berkeley: University of California Press, 1980.

MASPÉRO, Georges. Au temps de Ramsès et d'Assourbanipal. Paris: Hachette, 1912.

MENU, Bernadette. Droit-économie-société de l'Égypte ancienne. Versalles: Edição da Autora, 1984.

MORENZ, Siegfried. La religion égyptienne: essai d'interprétation. Trad. de L. Jospin. Paris: Payot, 1977. 
O'CONNOR, David. New Kingdom and Third Intermediate Period. In: TRIGGER, B.G. et al. Ancient Egypt: a social history. Cambridge: Cambridge University Press, 1983, p.183-278.

PETRIE, Flinders. Religious life in ancient Egypt. New York: Cooper Square, 1972.

POSENER, Georges et al. Dictionnaire de la civilisation égyptienne. 2 ed. Paris: Fernand Hazan, 1970.

ROMER, John. Ancient lives: the story of the Pharaohs' tombmakers. London: Weidenfeld \& Nicolson, 1984.

SAINTE FARE GARNOT, Jacques. Religions égyptiennes antiques: bibliographie analytique (1939-1943). Paris: Presses Universitaires de France, 1952.

SAUNERON, Serge. The priests of ancient Egypt. Trad. de Ann Morrissett. New York: Grove Press, 1980.

SEIDL, E. Die Gottesentscheidungen der Saiten- und Persezeit. In: Essays in honor of C. Bradford. New Haven: The American Society of Papyrologists, 1966, p. 59-65.

THÉODORIDĖS, Aristide. Du prestige de la procédure oraculaire parmi le personnel de la nécropole thébaine, sous le Nouvel Empire. Acta Orientalia Belgica, v. 10, p. 1-16, 1963 e 1964.

THÉODORIDĖS, Aristide. 'Les ouvriers-magistrats' en Égypte à l'époque ramesside. Revue Internationale des Droits de l'Antiquité, Bruxelas, v. 16, p. 103-188, 1969.

THÉODORIDĖS, Aristide. The concept of law in ancient Egypt. In: HARRIS, J. R. (ed.) The legacy of Egypt. 2 ed. Oxford: Clarendon Press, 1971, p. 291-322.

VANDIER, Jacques. La religion égyptienne. Paris: Presses Universitaires de France, 1949.

WILSON, John A. The culture of ancient Egypt. Chicago: The University of Chicago Press, 1951.

CARDOSO, C. F. S. La divination en Égypte Pharaonique. Clássica, São Paulo, 4: 53-65, 1991.

\footnotetext{
RÉSUMÉ: La divination en Égypte ancienne avait des rapports étroits avec le sacré. Les deux types connus, l'oniromancie, pourvue d'une documentation relativement pauvre, et les oracles, pourvus de sources plus nombreuses, éclairent les sphères du pouvoir pharaonique et sacerdotal de même que le quotidien populaire. En présentant des exemples spécifiques de divination et les controverses à leur sujet, on conclut qu'en Égypte ancienne a duré longtemps la notion selon laquelle, loin de concerner des entités lointaines et distantes, les dieux — ou tout au moins quelques — uns parmi eux - prennaient part dans la vie quotidienne des rois, des puissants et également des gens pauvres.

MOTS CLÉS: Égypte pharaonique, divination, oniromancie, oracles.
} 